\title{
STUDIU RETROSPECTIV AL CAZURILOR DE TRAUMATISME LA UN CABINET DE MEDICINA FAMILIEI, ÎN PERIOADA 2005-2009
}

\author{
Bumbuluț Călin ${ }^{1,2}$, Negru Alina Daniela ${ }^{1,3}$ \\ ${ }^{1}$ CMI Satu Mare, ${ }^{2}$ medic primar medicina familiei, instructor formator, ${ }^{3}$ medic specialist medicina familiei \\ corespondență: Satu Mare, str. Bobocului UK 30, email: bumbulutcalin@yahoo.com
}

Title: A retrospective review of trauma injuries cases at a family practice during the period of 2005-2009

Abstract:

Background. The diagnosis and therapeutical demeanour in superficial trauma injuries represents a small but significant part of the family practitioner's activity.

Objective. The aim of this study is to evaluate the statistical significance of incidence and rate of superficial trauma injuries in the setting of cases, based on types, age group and gender, at urban population, in a family medicine practice.

Methods. We carried out a retrospective study on the patients seen successively over a period between 2005 and 2009, at a family medicine practice from Satu Mare. The total body surface, were examined systematically, the characteristics and location of all recent injuries were recorded. The statistical method used for comparison was standard.

Results. We identified 714 superficial injuries from the analyse of 58.281 consultations, representing $1.23 \%$ of entire consultations and 3.36\% from acute cases. Between the age of 7 and 20, the rate male:female is almost constant twice as much for males. Females prevail until age of 3, when males become predominant, with a peak at age of 2-3, maintaining until the group of age over 60 , when the rate is reversing again in the favour of females. The injuries are 1.87 more frequent at males. The least small risc for injuries is for the group under one year of age and 1 to 4 , the increased is at 5 to 20 , almost 2.5 bigger than at 20-60 and over 60, at these last two the risc is approximately equal. At first place in order are the open wound, then musculary fondness, dislocations and sprains, the fractures of upper and lower limbs. The largest number of fractures are at active population of 20 to 60 years old, followed by the group of 8 to 14 , and 15 to 20 . The risk for fractures is maximal at 5 to 20 and reduced at 0 to 1 year old, and above average over 60 . The male have propensity for superficial injuries relative other injuries at the group of 8 to 14 and 15 to 20; female have propensity at others age groups, with a deviation of 15 times larger to the group of 2 to 3 years old towards injuris in general. The contusion wounds have an above average risk at 1 to 4 year group and 5 to 18 years with significant decrease for 19 to 60 years and over 60. The slash wounds prevail at upper limbs, frequently on the left; the pricked wounds prevail at lower limbs, frequently on the right; the contusion wounds prevail at head, specifically in the frontal area.

Conclusions. The knowledge of the type of injuries and the risk for it by age group, gender and event type, should be the basis for setting up prevention programs for communities, family and occupational medicine.

Key words: trauma, traumatic lesions, contusion wounds, slash wounds, pricked wounds, fractures, age groups, family medicine. 


\section{Rezumat}

Introducere în temă. Diagnosticul și stabilirea conduitei terapeutice în leziunile traumatice superficiale reprezintă o mică parte, dar importantă, din activitatea medicului de familie.

Obiective. Scopul studiului este de a evalua statistic incidența și proporția în ansambul cazurilor a leziunilor traumatice superficiale pe tipuri, grupe de vârstă și sex, în cadrul populației urbane, aflată în evidența cabinetului de medicina familiei.

Metode. Am efectuat un studiu retrospectiv pe pacienții examinaţi între ianuarie 2005 și martie 2009, la un cabinet de medicina familiei din Satu Mare. Au fost investigate toate regiunile corpului, înregistrându-se tipul leziunilor recente și localizarea lor. Am utilizat în prelucrarea datelor analiza statistică standard.

Rezultate. Am identificat 714 leziuni traumatice superficiale din analiza a 58.281 consultații, reprezentând 1,23\% din totalul consultațiilor și 3,36\% din cazurile acute. Între 7 și 20 de ani proporția traumatismelor între băieți și fete este aproape constant dublă în favoarea băieților. Sexul feminin predomină până la 3 ani, când sexul masculin devine preponderent, cu un maxim în grupa de vârstă de 2-3 ani, menținându-se până la grupa de vârstă de peste 60 ani, când se inversează din nou în favoarea sexului feminin. Traumatismele sunt de 1,87 de ori mai frecvente la sexul masculin. Cel mai mic risc pentru traumatisme este al grupelor de vârstă sub un an și 1-4 ani, cel mai mare fiind la grupa 5-20 ani, de aproape două ori și jumătate mai mare decât la grupele de 20-60 ani și peste 60 ani, la acestea ultime două fiind sensibil egal. Pe primul loc ca frecvență sunt leziunile deschise, apoi afecțiunile musculare, luxațiile și entorsele, fracturile membrelor superioare, fracturile membrelor inferioare. Cel mai mare număr de cazuri de fracturi s-a înregistrat la populația activă de 20-60 ani, urmată de grupa 8-14 ani, apoi 15-20 ani. Riscul pentru fracturi este maxim la 5-20 ani și mai redus la 0-1 ani și mai crescut decât media la peste 60 ani. Sexul masculin pentru grupele 8-14 ani și 15-20 ani are o predispoziție pentru traumatisme superficiale față de alte tipuri de traumatisme, la celelalte grupe de vârstă existând o predominanță a sexului feminin, la grupa 2-3 ani există o deviație de 15 ori mai mare, în favoarea sexului feminin față de traumatisme în general. Plăgile contuze au un risc peste medie la grupa 1-4 ani și 5-18 ani, cu o scădere semnificativă pentru 19-60 ani și peste 60 ani. Plăgile tăiate predomină la membrele superioare, mai frecvent stâng; plăgile înțepate mai frecvent la membrele inferioare, mai ales drept; plăgile contuze predomină la nivelul capului, în special la nivel frontal.

Concluzii. Cunoașterea tipului de traumatisme și a riscului pe grupe de vârstă și sex, precum și pe tipul de ocupație, ar putea constitui baza programelor de prevenție atât pentru colectivități, familie, cât și pentru medicina ocupațională.

Cuvinte cheie: traumatisme, leziuni traumatice, plăgi contuze, plăgi tăiate, plăgi înțepate, fracturi, grupe de vârstă, medicina familiei.

Deși reprezintă un procent foarte mic din cazuri, traumatismele reprezintă situații cu mare impact psihologic asupra pacienților și aparținătorilor, fiind uneori impresionante ca simptomatologie, semne clinice și circumstanțe de apariție, față de cazurile obișnuite dintr-un cabinet de medicina familiei.

Am colectat datele provenind din consultațiile efectuate la Cabinetul de medicina familiei pe perioada 2004-2009 (trimestrul I), utilizând programul de evidență primară al cabinetului, cuprinzând 58.281 consultații, din care 714 au fost traumatisme de diferite tipuri. Incidența medie anuală a traumatismelor pe perioada menționată a fost de 75 la mie. Procentul traumatismelor din totalul consultațiilor în perioada menționată a fost de doar 1,23\%, dar dacă luăm în considerare proporția de 43,62\% cazuri acute și controale ale acestora, respectiv de 36,43\% cazuri acute, rezultă un procent de 2,81\% din totalul cazurilor acute și controalele lor, respectiv 3,36\% din totalul cazurilor acute (Figura 1).

Tipurile de traumatisme analizate au fost:

-leziuni traumatice superficiale: plăgi deschise (contuze, tăiate, mușcate, înțepate), contuzii -fracturi, luxații, entorse 
-întinderi ligamentare și musculare, sinovite, miozite și mialgii posttraumatice -alte leziuni (abraziuni, escoriații, echimoze, hematoame).

\section{structura consultațiilor}

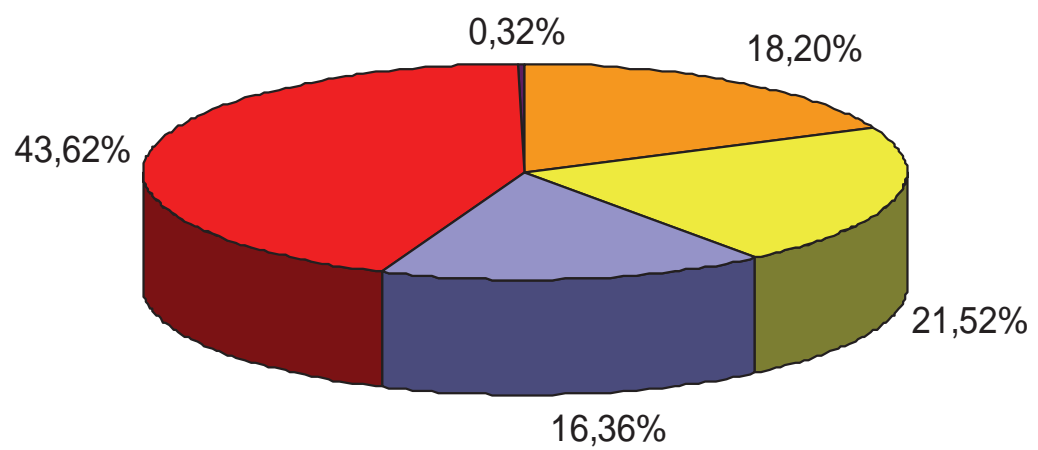

\begin{tabular}{|ll|}
\hline profilaxie primară & $\square$ profilaxie secundară $\quad \square$ eliberări acte medico-legale \\
$\square$ boli acute şi controalele lor $\quad \square$ tratamente de mică chirurgie
\end{tabular}

Fig. 1. Structura consultațiilor pe tipuri

La Spitalul Centrului Medical din Vermont, SUA a fost efectuat un studiu prospectiv pe un eșantion de 30\% din pacienții care au primit îngrijiri medicale în decursul unui an [1], fiind identificate în special leziuni superficiale ale pielii la copii sub zece ani, leziuni de suprasolicitare la grupa 10-59 ani, iar la vârstnici fracturi. Dintre bărbații cu vârstă între 20-59 ani cu traumatisme, 31\% dintre ele erau legate de muncă, iar în cazul femeilor în 26\%. Cele mai frecvente obiecte incriminate în traumatisme au fost echipamentele recreaționale (24\%) și vehiculele motorizate (9\%), cea mai frecventă cauză a traumatismelor fiind impactul cu planul dur al solului (20\%), urmat de materiale de construcție și din structura caselor (17\%).

Pe o perioadă de opt ani, între 1992 și 1999, la departmentele de urgență din SUA, conform datelor Centrului Național pentru Statistică Medicală (National Center for Health Statistics -NCHS) [2], s-a înregistrat o rată a traumatismelor de 108,2 la 1000 copii, fără diferențe semnificative în funcție de sex, rată, etnie, din care $6 \%$ au fost internate, rata de internare fiind de 6,1 la 1000 . Majoritatea traumatismelor au fost casnice, la nivelul capului fiind înregistrate 12\% (rata leziunilor 13,4 la mie pe an), în 21\% din cazurile de leziuni traumatice la nivelul craniului fiind fracturi sau leziuni intracraniene. Traumatismele feței au avut o rată de 30,2 la mie, cele ale extremităților 23,9 la mie, plăgile deschise sau leziuni superficiale fiind asociate multor din aceste traumatisme. Fracturile extremităților au reprezentat $4 \%$ din cazuri (rată anuală 4,6 la mie). Cea mai frecventă cauză a traumatismelor au fost căderile (35,1 la mie), apoi accidentele auto (8,8 la mie), corpii străini (5,2 la mie), otrăvirile (3,8 la mie). O comparație privind rata mortalității infantile arată un raport leziuni nonfatale:leziuni fatale 8789:1, în raportul accidentelor auto nonfatale:fatale 197:1, iar în otrăviri 1271:1. Traumatismele nonfatale întrec cu mult pe cele fatale; leziunile prin cădere sunt obişnuite, dar rareori fatale.

În ceea ce privește variația lunară a consultațiilor în cabinetul de medicina familiei, pe media multianuală există două maxime: martie și octombrie, trei minime: iulie, august, decembrie, iar în variația lunară a traumatismelor pe media multianuală se regăsesc maximele în mai și octombrie, minimele fiind în iunie, august, decembrie. Dacă analizăm în schimb variația lunară a traumatismelor pe fiecare an, observăm mari diferențe între maxime și minime, dispersia fiind maximă, ceea ce 
înseamnă că variația medianei reflectă doar rezultatul unui calcul statistic și nu urmează o tendință sezonieră sau lunară multianuală. În concluzie nu putem stabili o corelație între variația lunară a consultațiilor și variația lunară a traumatismelor, putând exista doar o relație strict de proporționalitate cu numărul consultațiilor. (Figura 2,3)

variația lunară a traumatismelor 2004-2008

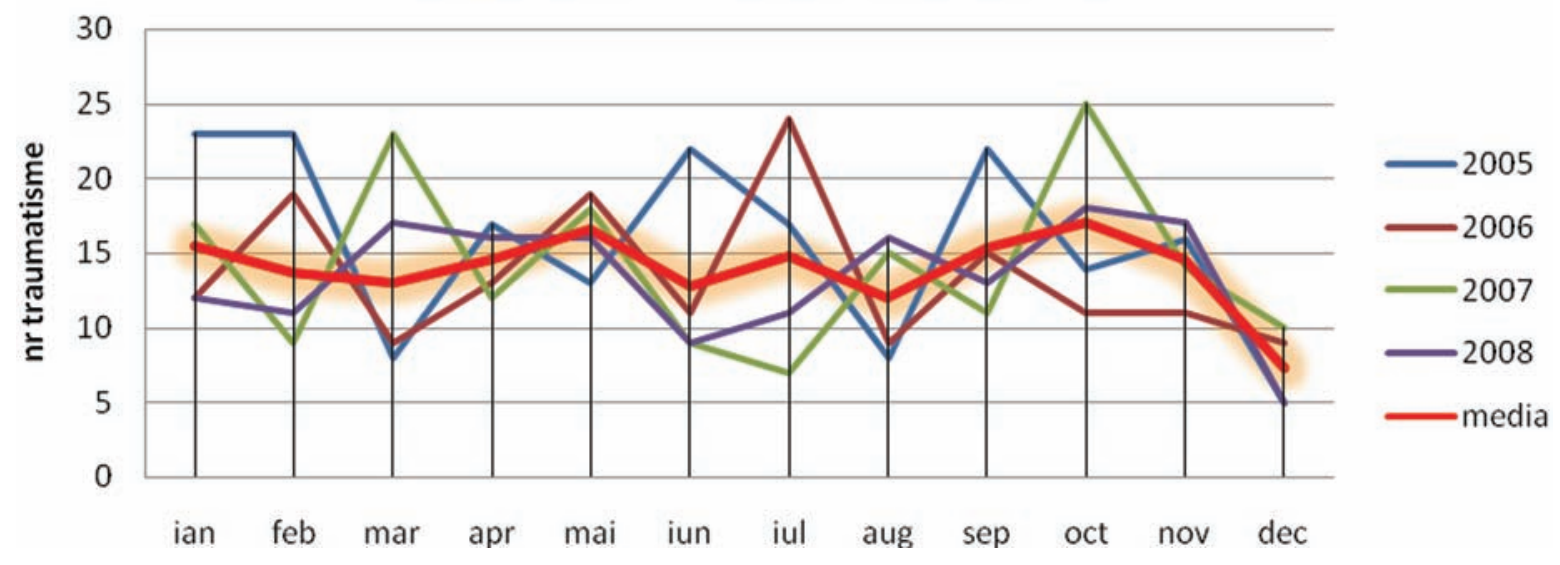

Fig.2. Variația lunară a numărului de traumatisme

variația lunară a consultațiilor 2004-2008

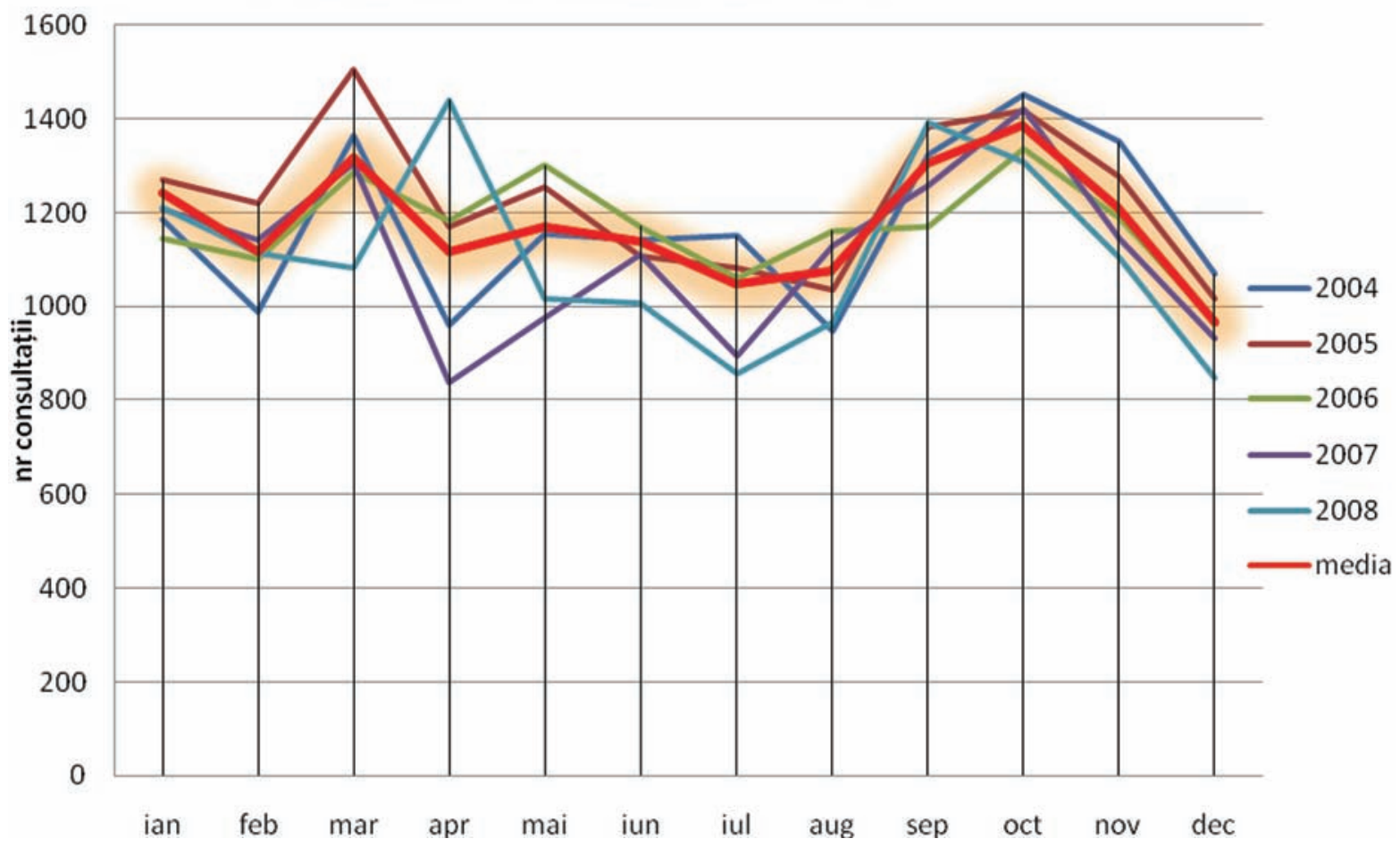

Fig. 3. Variația lunară a numărului de consultații 


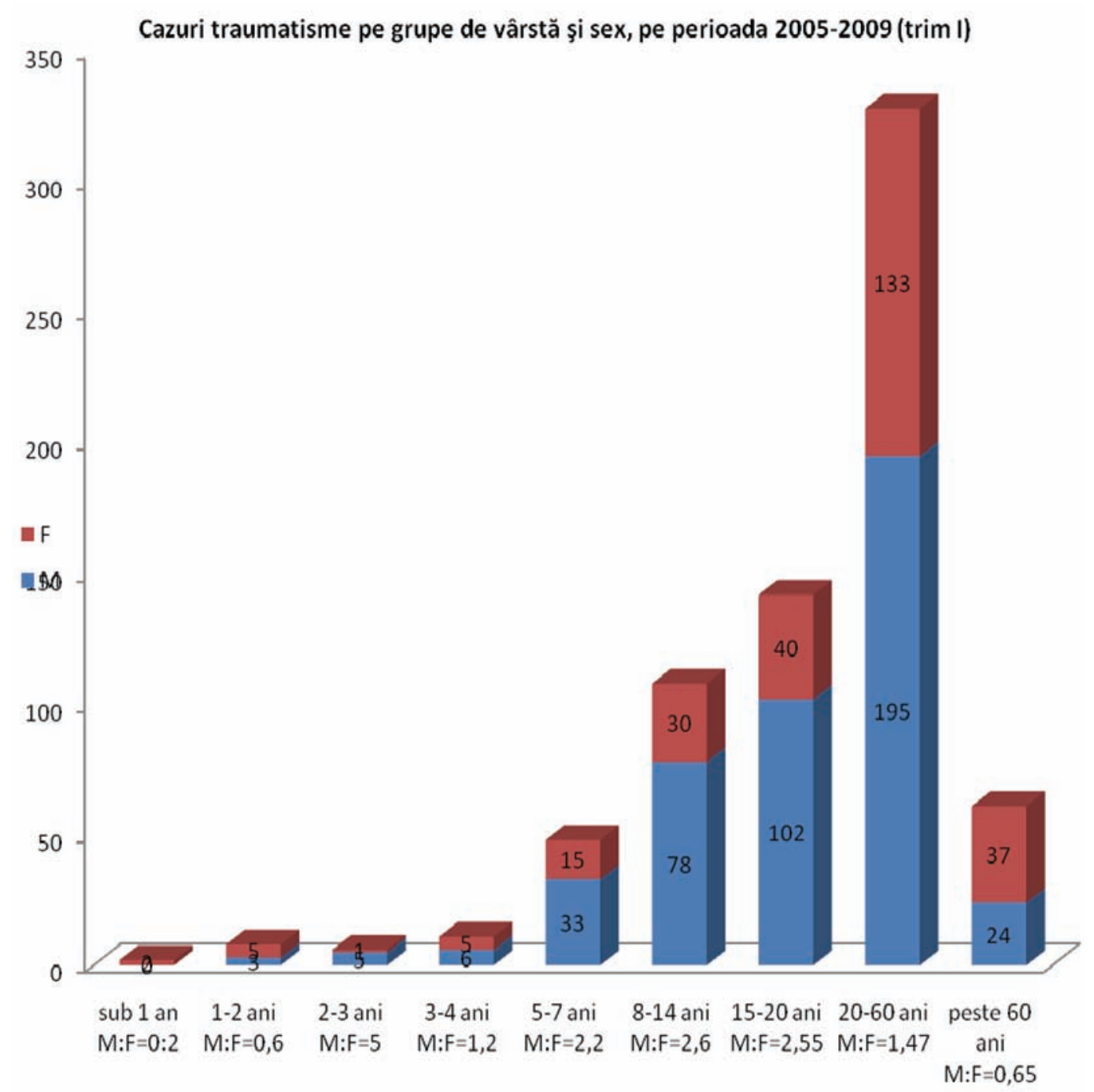

Fig. 4. Cazuri traumatisme pe grupe de vârstă şi pe sex

Raportul între sexe a fost în favoarea sexului feminin până la 3 ani (între 0,2 și 0,6 ), când sexul masculin devine preponderent, cu un maxim în grupa de vârstă de 2-3 ani la o proporție de 5 la 1 , menținându-se până la grupa de vârstă de peste 60 ani, când se inversează din nou în favoarea sexului feminin (M:F=0,65). De observat că între 7 și 20 de ani proporția traumatismelor între băieți și fete este aproape constant dublă în favoarea băieților (între 2,2 și 2,55) (Figura 4). Pe ansamblu, proporția între sexe a cazurilor de traumatisme a fost $\mathrm{M}: \mathrm{F}=1,66$, iar în lista de pacienți proporția generală $\mathrm{M}: \mathrm{F}$ este de 0,89 , deci din punct de vedere statistic, traumatismele predomină semnificativ la sexul masculin, fiind de 1,87 de ori mai frecvente (Figura 6).

În ceea ce privește situația generală a numărului de cazuri noi de boală diagnosticate există o predominanță a sexului masculin sub 1 an (B:F 1,47), o proporție relativ egală între sexe între 1-14 ani și predominanța sexului feminin între 15-64 ani (B:F 0,61) și peste 65 ani (B:F 0,62) (Figura 5). Pe totalul populației depistarea de noi cazuri de boală predomină la sexul feminin (B:F 0,8$)$. 


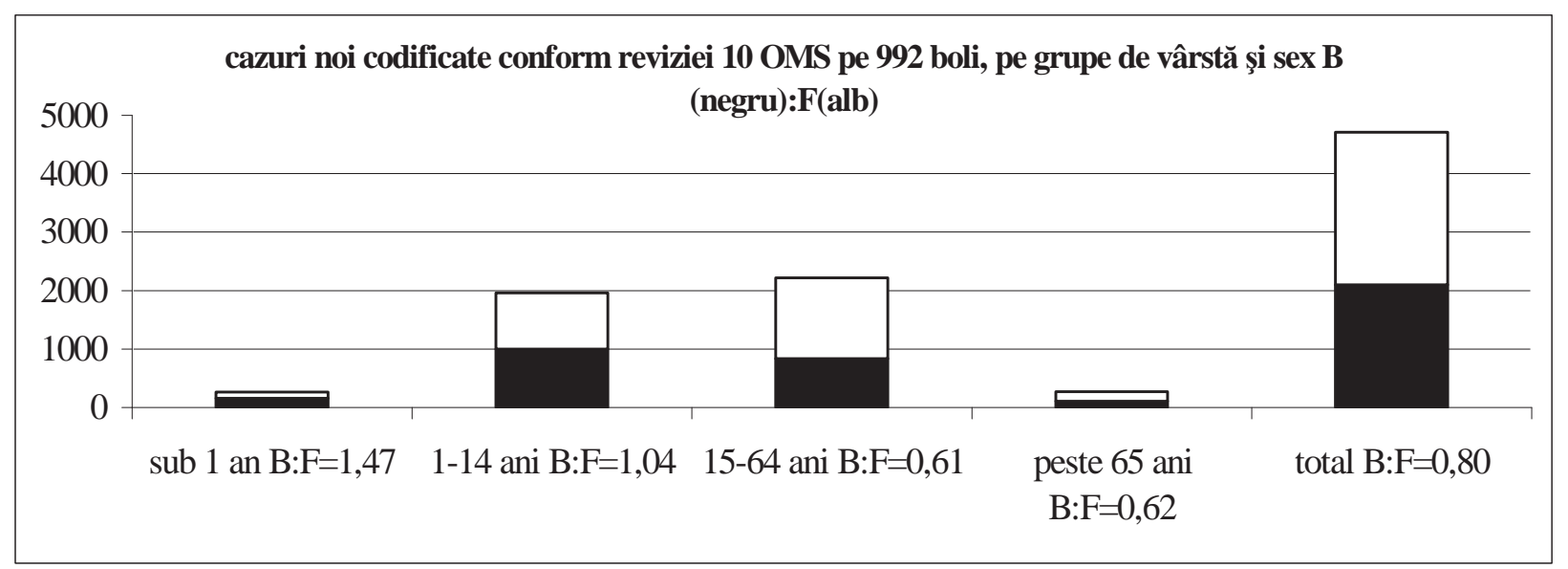

Fig. 5. Cazuri noi de boală pe grupe de vârstă şi sex

\section{raportul sex masculin:sex feminin populația generală vs. traumatisme}

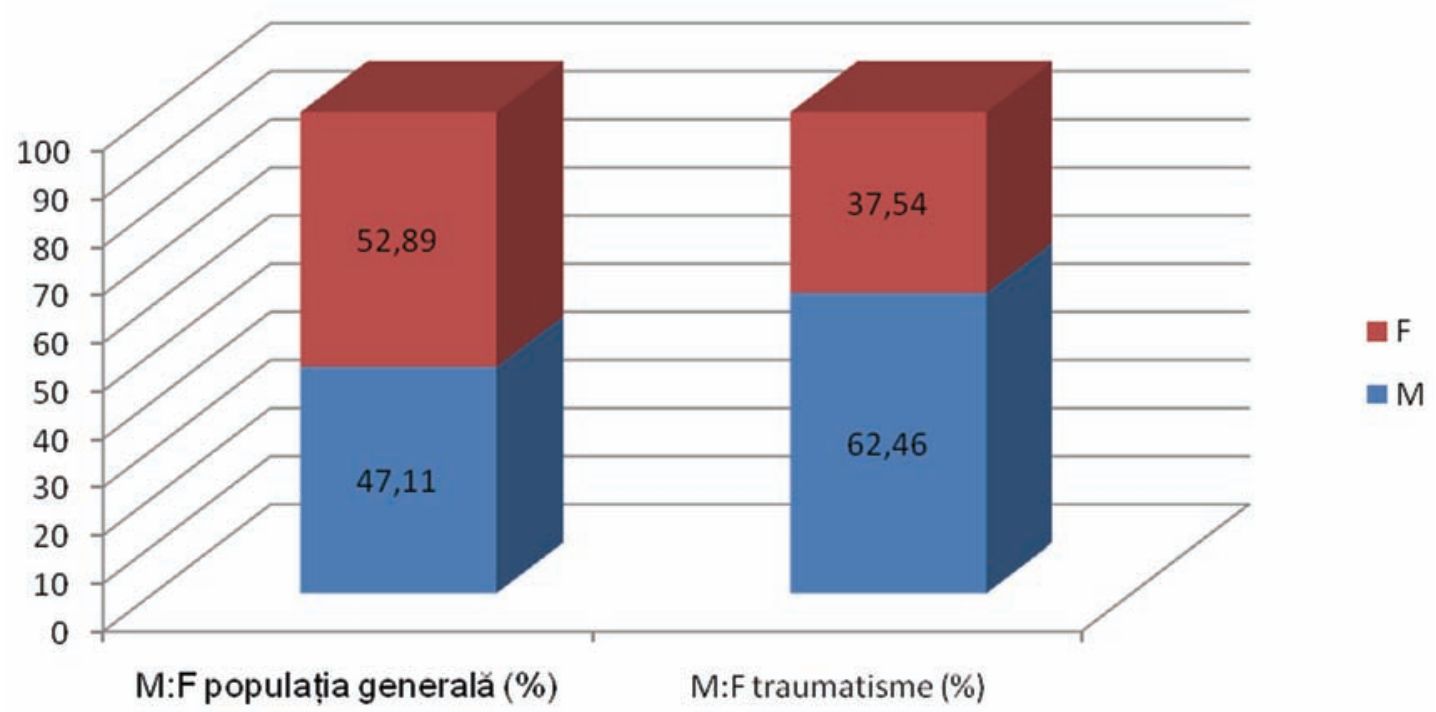

Fig. 6. Raportul sex masculin:sex feminin în populația generală versus cazuri traumatisme

Prelucrarea statistică ne permite să apreciem riscul pentru traumatisme al unei grupe de vârstă folosind indicele de risc, adică raportul dintre procentul grupei de vârstă și procentul traumatismelor la acea grupă: cel mai mic risc este al grupelor de vârstă sub un an și 1-4 ani, cel mai mare fiind la grupa 5-20 ani, de aproape două ori și jumătate mai mare decât la grupele de 20-60 ani și peste 60 ani, la acestea ultime două fiind sensibil egal (Figura 7). 
riscul de traumatisme în funcție de grupa de vârstă

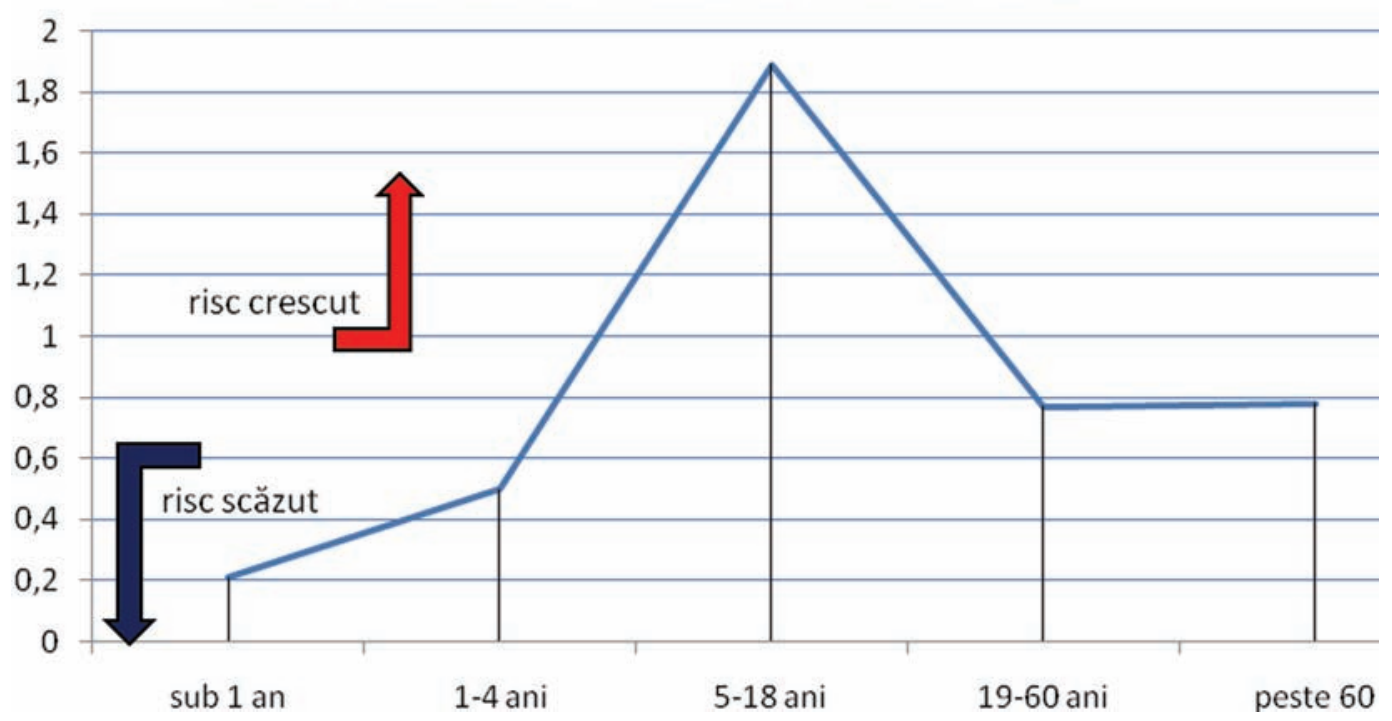

Fig. 7. Riscul general pentru traumatisme pe grupe de vârstă

După tipul traumatismului, ca și frecvență pe primul loc, cu mai mult de jumătate din cazuri $(53,92 \%)$, sunt leziunile traumatice deschise (plăgile și contuziile), apoi afecțiunile musculare (întinderi, rupturi) (14,71\%), luxațiile și entorsele (13,31\%), fracturile membrelor superioare $(7,42 \%)$, fracturile membrelor inferioare $(4,48 \%)$ (Figura 8,9$)$.

\section{Tipul traumatismului CIM 10}

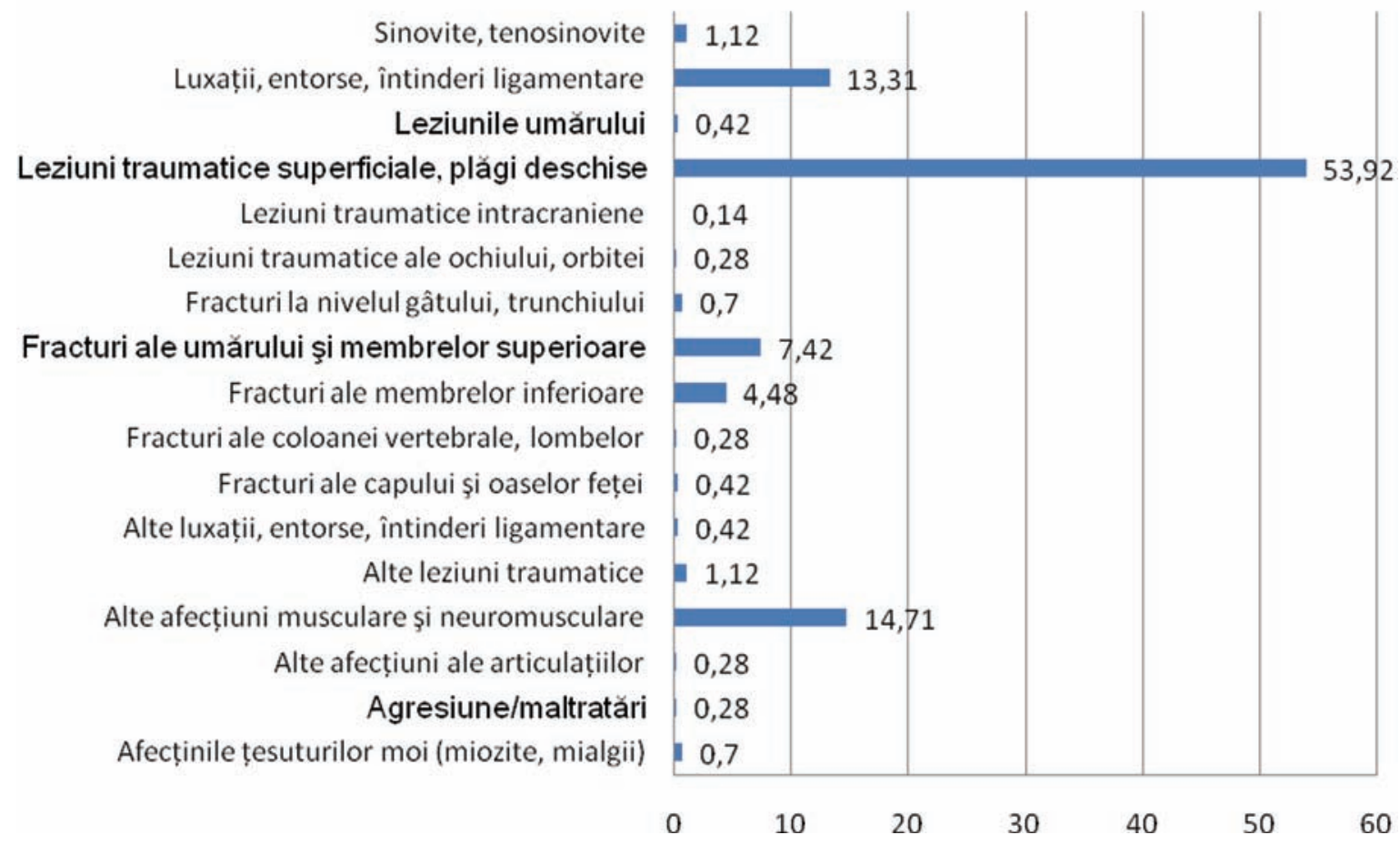

Fig. 8. Proporția traumatismelor pe tipuri după clasificarea CIM 


\section{traumatisme}

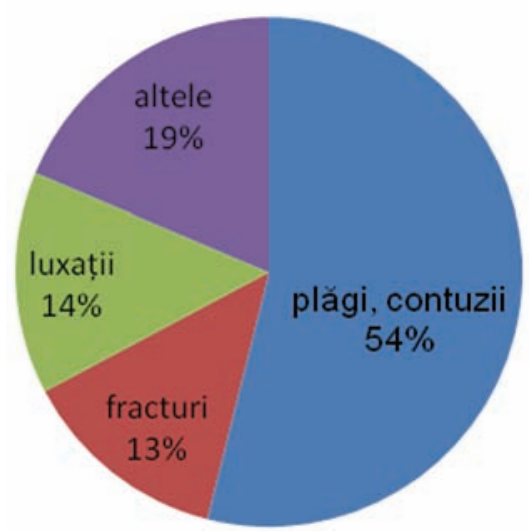

Fig. 9. Proporția traumatismelor pe grupe

Între 1998 și 2004, în Suedia au fost spitalizate 743.022 traumatisme, din care $24 \%$ au fost reinternări. Pentru a determina dacă aceste internări au fost pentru traumatisme noi sau reinternări pentru traumatisme mai vechi [5], a fost elaborat un model de predicție pentru cazuri noi de traumatisme în funcție de vârstă, tipul de internare (urgență sau nu), timpul scurs de la internarea pentru un traumatism anterior, diagnosticul principal și tipul de secție implicată, model care a dovedit că traumatismul cel mai frecvent implicat în reinternare a fost contuzia (35\%).

Într-un studiu sud african [3] efectuat pe copii până la 17 ani pe o perioadă de un an în care au fost examinați pentru diferite motive, majoritatea copiilor de peste nouă luni au avut cel puțin o leziune recentă a pielii, fără diferență de sex, $70 \%$ au avut cel puțin cinci leziuni, $4 \%$ au avut peste zece, sub $1 \%$ au avut peste 15 , iar $0,2 \%$ au avut peste 20 . Au fost afectate în special membrele inferioare, în special gambele și genunchii; mai puțin de $2 \%$ din copii au prezentat leziuni ale toracelui, abdomenului, pelvisului, feselor, iar sub 1\% ale feței, urechilor sau gâtului. Majoritatea leziunilor au fost plăgi superficiale, indiferent de momentul din cursul anului, totuși fiind observate mai multe leziuni vara, într-o regiune având climat temperat, când au predominat plăgile contuze și abraziunile. Grupa de vârstă 0-8 luni a fost unică din toate punctele de vedere, leziunile superficiale ale pielii find rare $(11,4 \%)$, neavând variabilitate sezonieră, fiind localizate la nivelul capului și feței, constând în special în abraziuni, contuziile reprezentând doar 1,2\%.

Un alt studiu [4] a investigat incidența și caracteristicile traumatismelor casnice în șase țări europene: Austria, Danemarca, Franța, Olanda, Portugalia și Suedia, la un număr de 88.567 copii între 0-18 ani, între 2003-2004. Incidența traumatismelor casnice a fost de 44,9 la mia de locuitori, fiind identificate șase tipuri utilizând analiza cluster: plăgi deschise ale capului, internări pentru contuzii, abraziuni, căderi pe scară, fracturi și luxații ale extremităților superioare, plăgi contuze, tăiate, înțepate, ale degetelor, alte leziuni. Traumatismele casnice ale copiilor reprezintă o problemă de sănătate publică importantă, în special la grupa de vârstă de 0-4 ani.

Compararea indicilor de risc pentru diferitele tipuri de traumatisme din studiul nostru arată o predispoziție generală pentru toate tipurile de traumatisme a grupei de vârstă 5-18 ani, cu un maxim de risc pentru luxații pentru această grupă și unul relativ egal pentru plăgi, contuzii și fracturi. La grupa de vârstă de peste 60 ani se observă o tendință de creștere a riscului pentru fracturi comparativ cu alte tipuri de traumatisme, cu o scădere semnificativă a celui pentru luxații (Figura 10). 


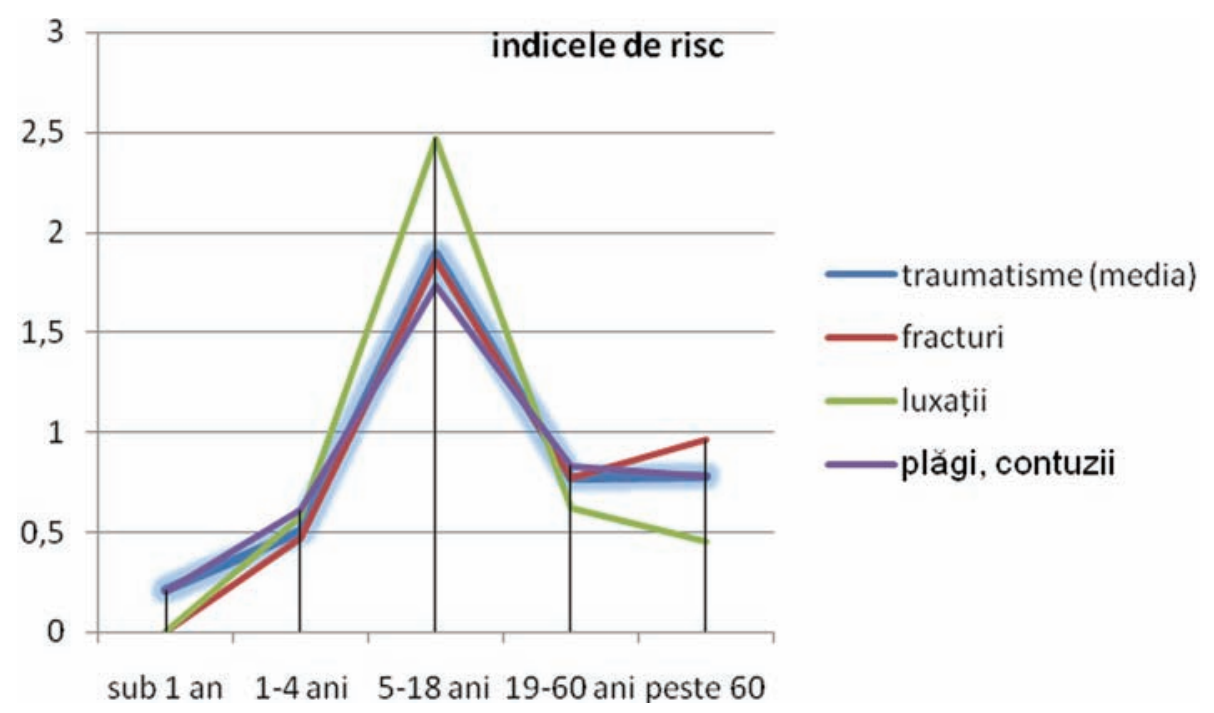

Fig. 10. Compararea indicelui de risc pe grupe de traumatisme

După localizare, pe primul loc sunt fracturile membrelor superioare cu peste jumătate din cazuri, urmate de cele ale membrelor inferioare cu o treime din cazuri, apoi ale trunchiului și gâtului, capului și oaselor feței, pe ultimul loc fiind cele ale coloanei vertebrale (Figura 11).

\section{fracturi după localizare}
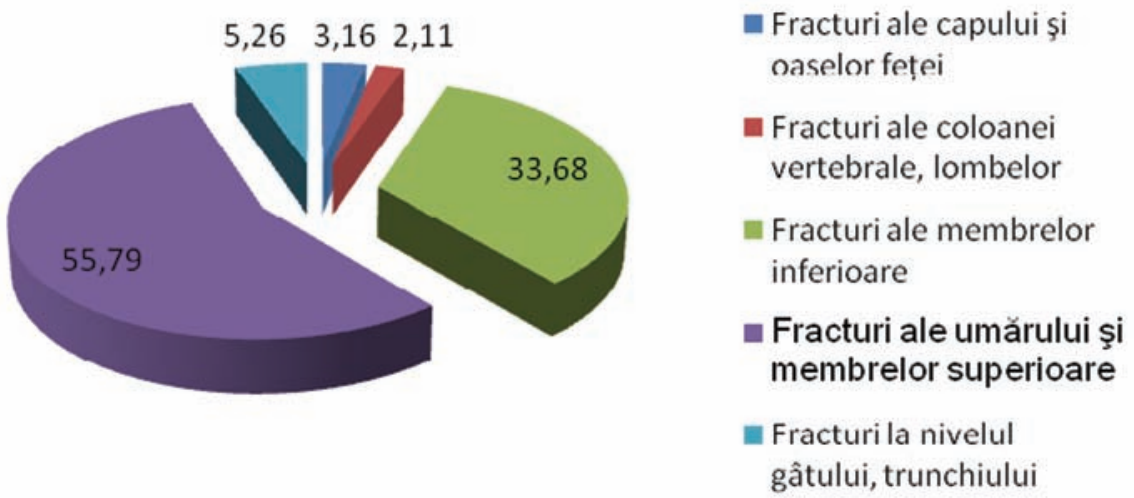

Fig. 11. Localizarea fracturilor

Cel mai mare număr de cazuri de fracturi s-a înregistrat la populația activă de 20-60 ani, urmată de grupa 8-14 ani, apoi 15-20 ani, la grupele sub 1 an și 2-3 ani nefiind înregistrat nici-un caz. Indicele de risc pentru fracturi urmează tendința indicelui de risc global pentru traumatisme, cu maxim la 5-20 ani și mai redus la 0-1 ani, dar mai crescut decât indicele mediu la peste 60 ani (Figura 12).

Pe o perioadă de patru ani, între 2001-2004, în departamentele de urgență din SUA au fost tratați pentru traumatisme 1.314.000 copii, adică aproximativ un copil la 1,5 minute [7]. Dintre acestea cele mai frecvente traumatisme nonfatale au avut ca şi cauză căderile. Pe ansamblu pacienții de sex masculin au fost mai frecvent afectați 52,2\% decât sexul feminin 44,8\%. Diagnosticul predominant au fost contuziile şi abraziunile $26,7 \%$. Contuziile/abraziunile, lacerațiile, hematoamele, corpii străini şi plăgile înțepate au fost mai frecvente în regiunea capului şi gâtului. Peste o treime din fracturi $(37,2 \%)$ au fost la brațe şi mâini.

Luxațiile, în studiul nostru, predomină la populația activă de 20-60 ani, incidența luxațiilor fiind mai mare decât a fracturilor la grupele de vârstă de 8-14 şi 15-20 ani. Indicele de risc pentru luxații 
depăşeşte semnificativ riscul mediu pentru traumatisme la grupa de vârstă 5-18 ani şi scade semnificativ la grupa de peste 60 ani (Figura 13).

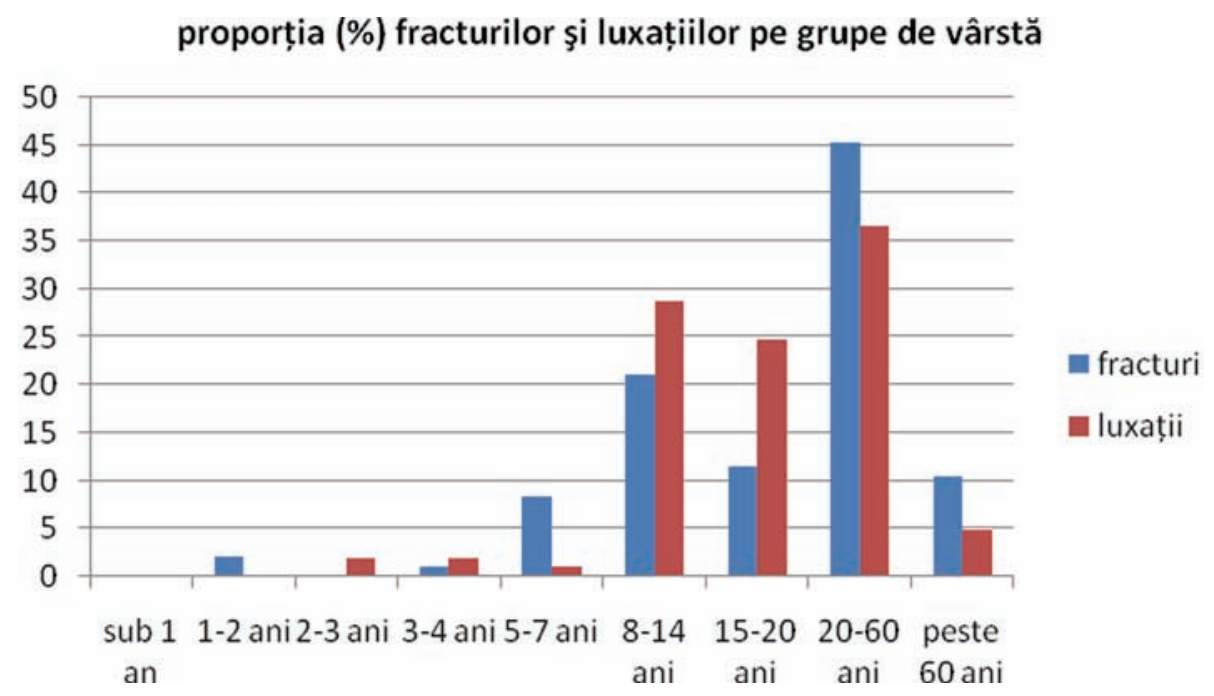

Fig. 12. Proporția fracturilor şi luxațiilor pe grupe de vârstă

Analizând global cazurile de leziuni traumatice superficiale pe grupe de vârstă constatăm predominența numărului de cazuri la grupa de vârstă de 20-60 ani, cu excepția numărului de plăgi contuze, unde numărul maxim de cazuri este la grupa 5-7 ani. Numărul cazurilor de plăgi înțepate faţă de alte tipuri de leziuni este maxim la grupa 15-20 ani (Figura 13).

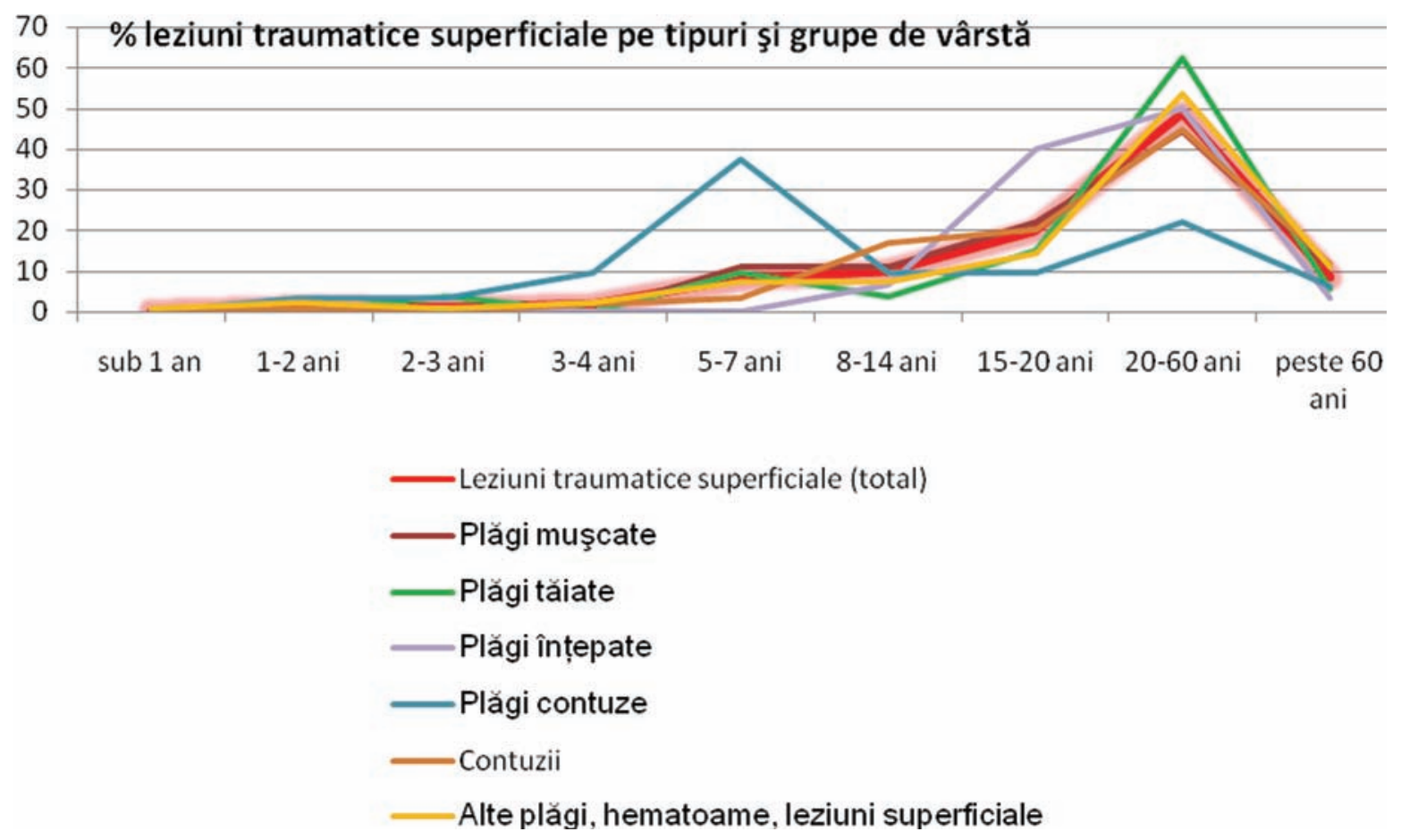

Fig 13. Procentul leziunilor traumatice superficiale pe grupe de vârstă

Pe sexe, cel masculin predomină în toate tipurile de leziuni traumatice superficiale (Figura 14). 
raportul M:F pe diferitele tipuri de leziuni traumatice superficiale vs. populația generală

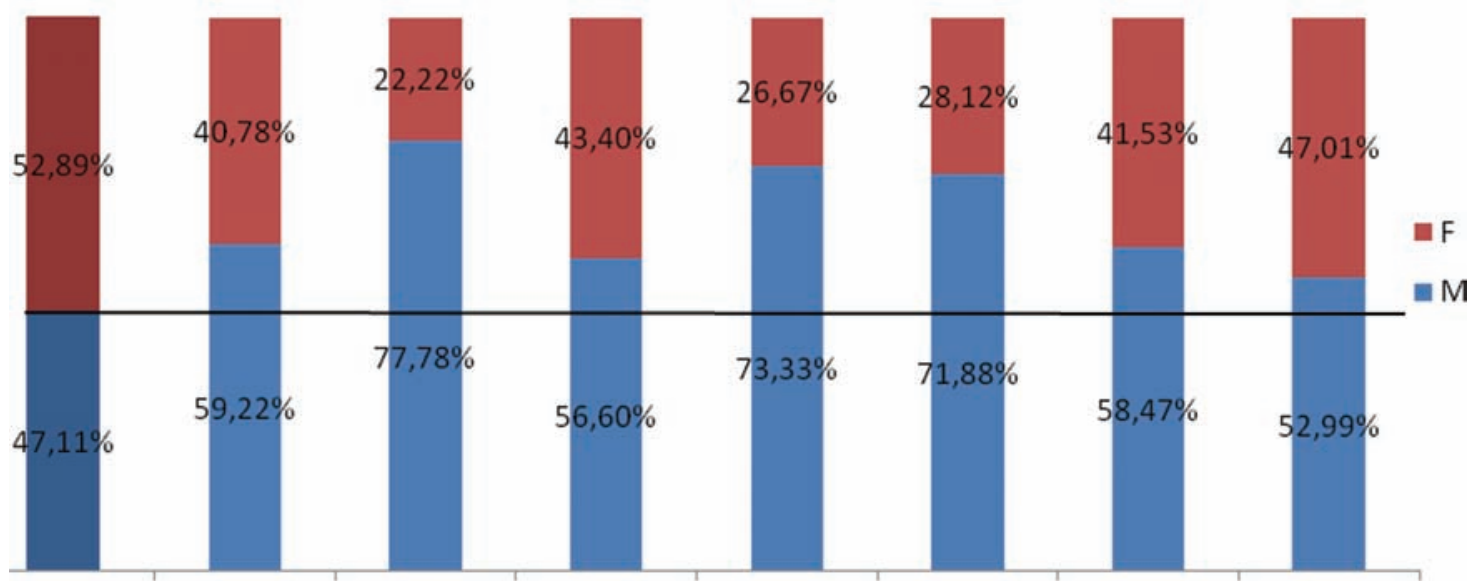

Popgen Lez tr superf(tot) PI. muşcate Plăgităiate Plăgi înțepatePlăgi contuze Contuzii Alte leziuni superf

Fig 14. Raportul de cazuri sex masculin:sex feminin pe tipuri de leziuni traumatide superficiale versus populația generală

Analiza indicelui de risc pe sexe și pe tipuri de leziuni superficiale (raportul dintre procentul corespunzător sexului în grupa de afecțiuni și procentul corespunzător sexului în populația generală) arată diferențe semnificative între cele două sexe, în sensul predominenței celui masculin, în cazul plăgilor mușcate, plăgilor înțepate și plăgilor contuze, cu o echilibrare a riscului între sexe pentru plăgi tăiate, contuzii și alte tipuri de leziuni traumatice superficiale (Figura 15).

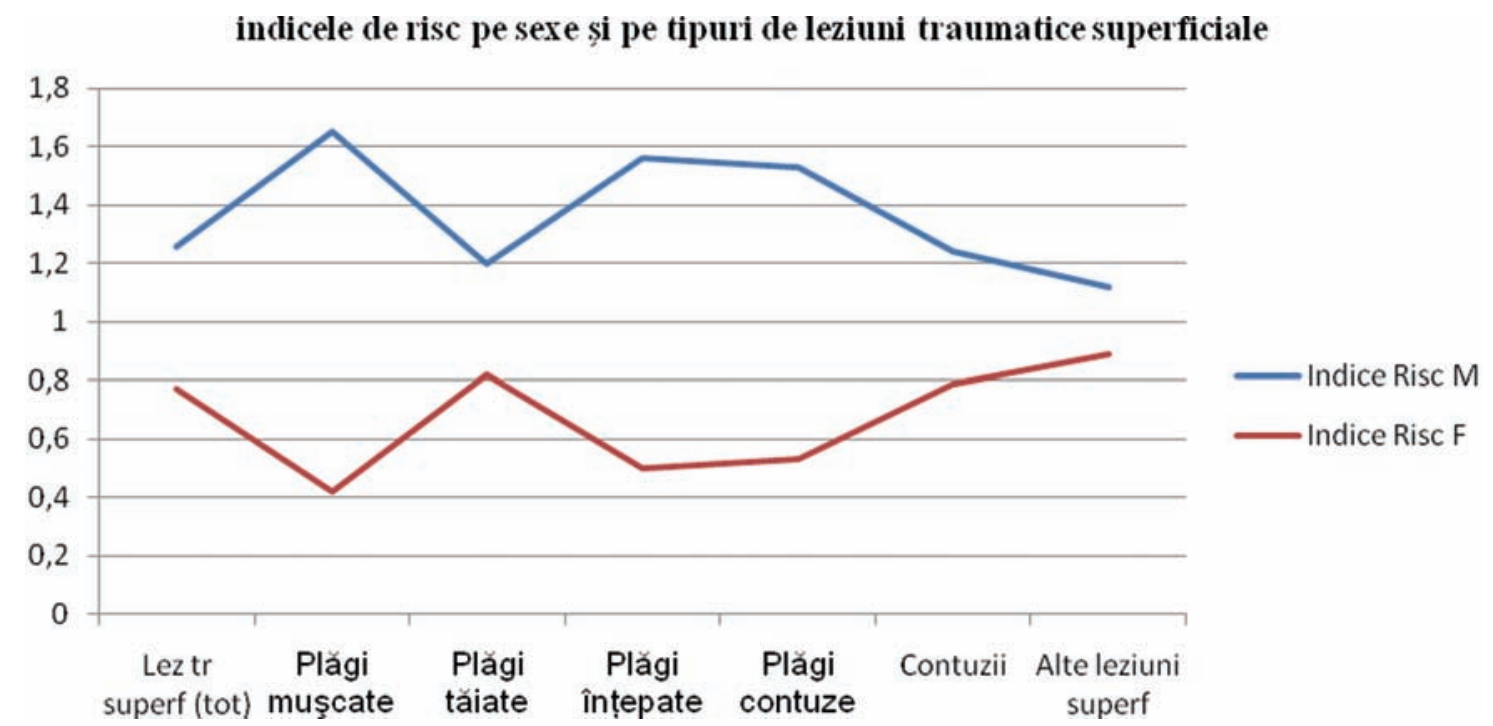

Fig. 15. Indicele de risc pe sexe şi pe tipuri de leziuni traumatice superficiale

Din analiza indicelui de risc pe diferitele tipuri de leziuni traumatice, constatăm o valoare peste medie a riscului pentru plăgi contuze pentru grupa de vârstă 1-4 ani şi 5-18 ani, cu o scădere semnificativă a riscului pentru 19-60 ani și peste 60 ani (Figura 16). La grupa sub un an riscul pentru plăgi contuze, mușcate, tăiate, înțepate, și pentru contuzii este practic nul, existând risc moderat pentru alte tipuri de leziuni traumatice. Pentru toate tipurile de plăgi grupa de vârstă de 5-18 ani este cu risc maxim, riscul pentru plăgi tăiate și înțepate scăzând semnificativ peste 60 ani. Este interesant faptul că riscul pentru plăgi mușcate și contuzii depășește semnificativ media la grupa de vârstă de peste 60 de ani, iar pentru plăgile tăiate grupa de vîrstă de 19-20 ani prezintă risc peste medie, deși numărul total de plăgi tăiate este mai mare la grupa 20-60 ani. 


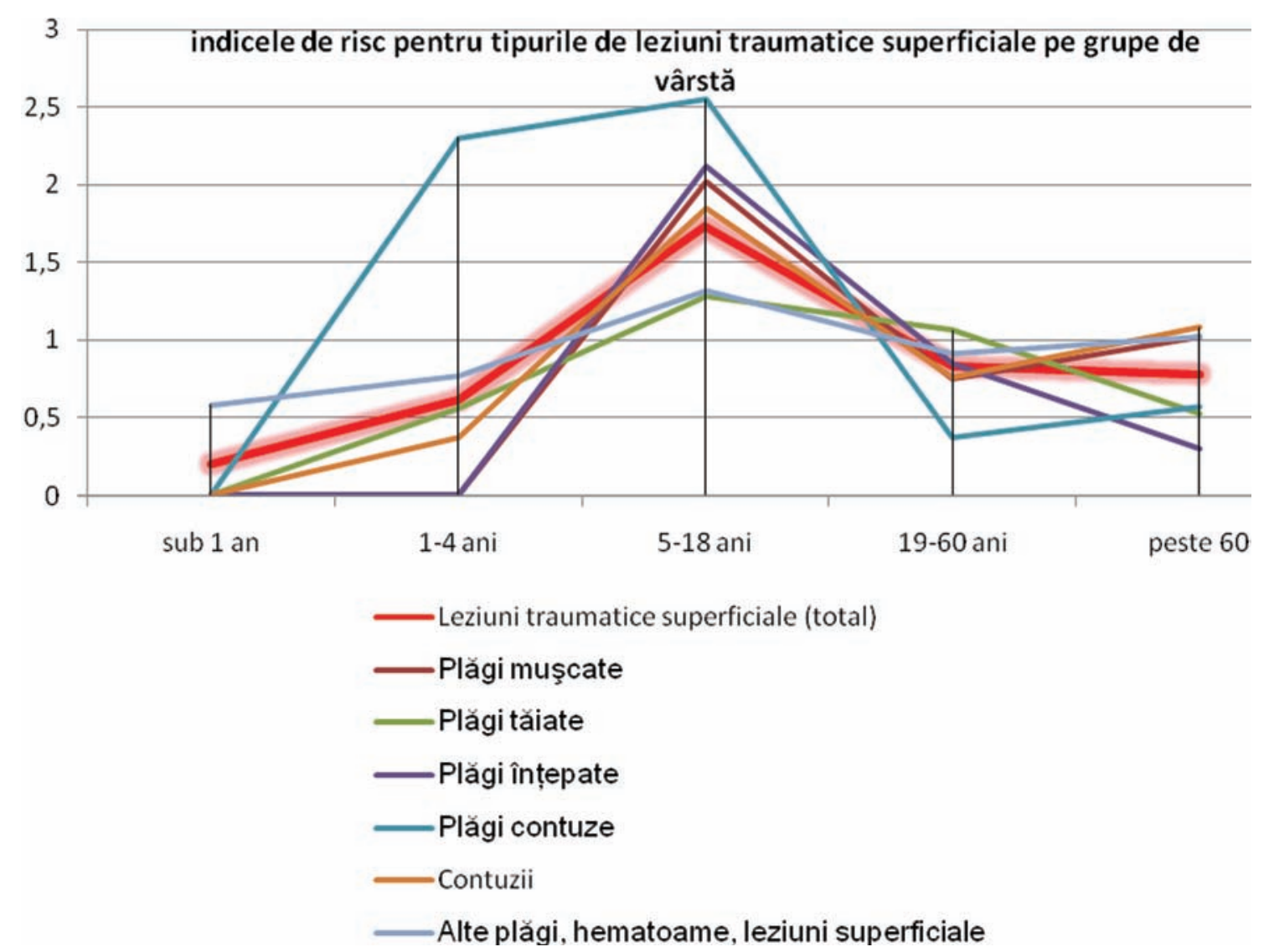

Fig. 16. Indicele de risc pe grupe de vârstă pentru diferite tipuri de leziuni traumatice superficiale

Plăgile mușcate au reprezentat $1,5 \%$ din totalul prezentărilor la serviciile de traumatologie pediatrică din Africa de Sud [6], iar 68\% din cazuri au fost la sexul masculin. Copii sub șase ani au fost mai predispuși la leziuni ale capului, feței sau gâtului, iar cei peste șase ani au prezentat leziuni ale perineului, feselor, coapselor sau picioarelor.

Din analiza raportului sex masculin:sex feminin în cazul traumatismelor superficiale faţă de traumatisme în general, observăm că sexul masculin are o predispoziție mai mare pentru traumatisme superficiale (plăgi tăiate, înțepate, mușcate, contuze și contuzii), față de alte tipuri de traumatisme (fracturi, luxații, etc), pentru grupele de vârstă 8-14 ani și 15-20 ani, la celelalte grupe de vârstă existând o predominanță a sexului feminin, cu mențiunea că la grupa de vârstă 2-3 ani există o deviație importantă, de 15 ori mai mare, în favoarea sexului feminin faţă de traumatisme în general (Figura 17).

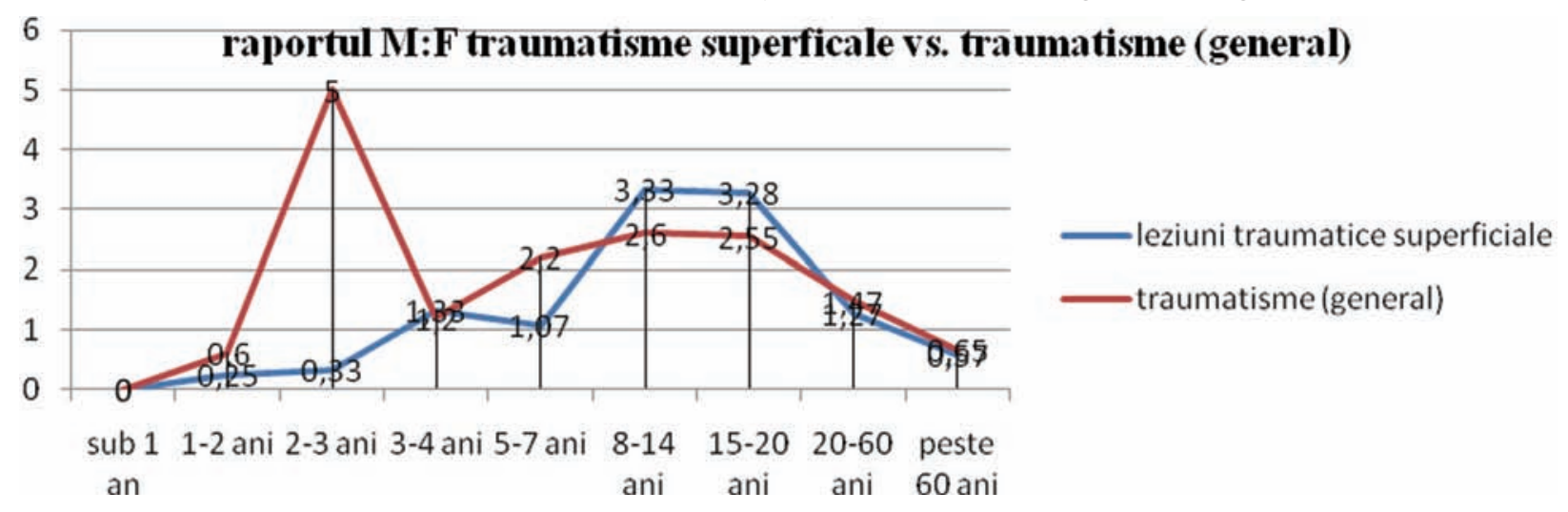

Fig. 17. Raportul sex masculin:sex feminin în traumatisme superficiale vs. traumatisme în general 
Pe ansamblul tipurilor de traumatisme superficiale, raportul sex masculin:sex feminin, arată o predominanță față de media traumatismelor superficiale a sexului masculin la grupele de vârstă 2-3 ani, cu excepția contuziilor, cu menținerea predominanței sexului masculin la 3-4 ani și la 5-7 ani, precum și peste 60 de ani, doar la plăgile contuze (Figura 18). O mențiune pentru predominanța afectării sexului masculin peste media leziunilor traumatice superficiale în cazul plăgilor mușcate, la grupele 15-20, 20-60 și peste 60 ani, precum și pentru plăgile înțepate la 20-60 și peste 60 ani.

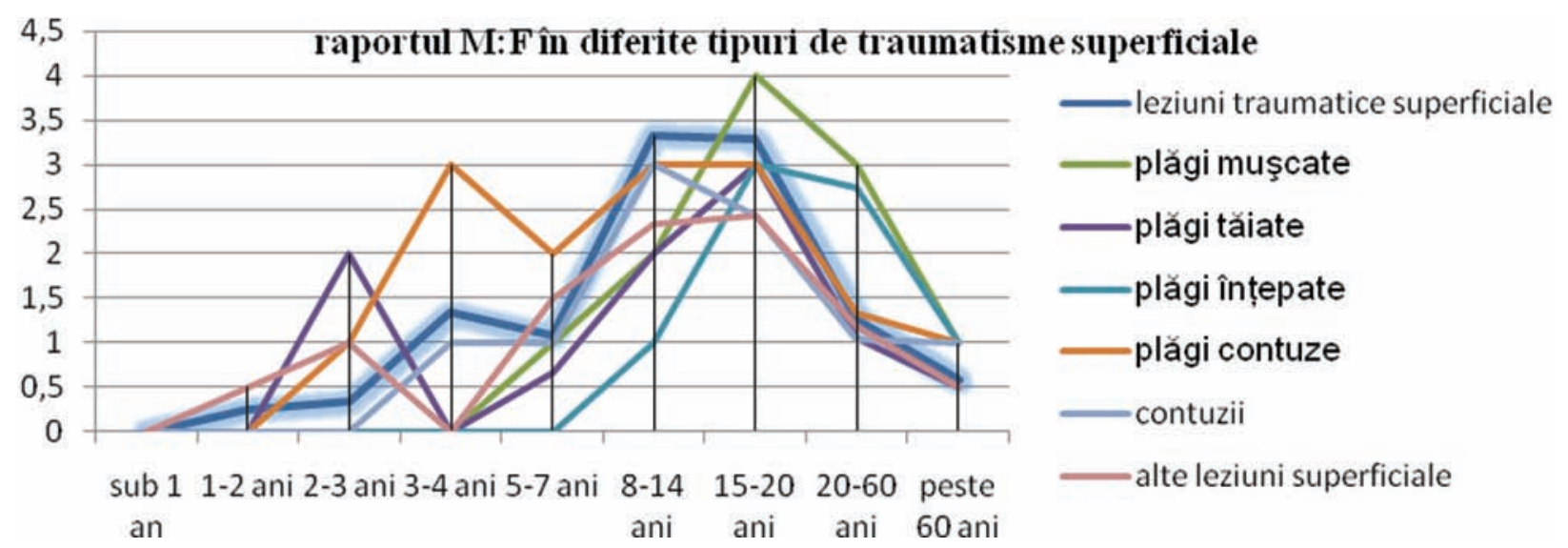

Fig. 18. Raportul sex masculin:sex feminin în diferite tipuri de traumatisme superficiale

Plăgile tăiate, după localizare, predomină la membrele superioare, membrul superior stâng fiind semnificativ mai frecrent afectat (Figura 19).

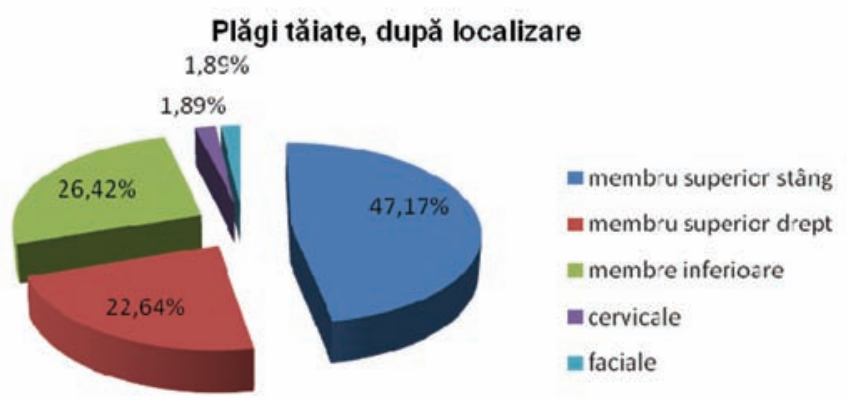

Proporția plăgilor tăiate între membrele superioare

Fig. 19. Dispoziția plăgilor tăiate pe segmentele corpului şi proporția plăgilor tăiate între membrele superioare

Plăgile înțepate sunt mai frecvente la membrele inferioare, cu predominanța afectării membrului inferior drept (Figura 20).

Plăgi înțepate, după localizare

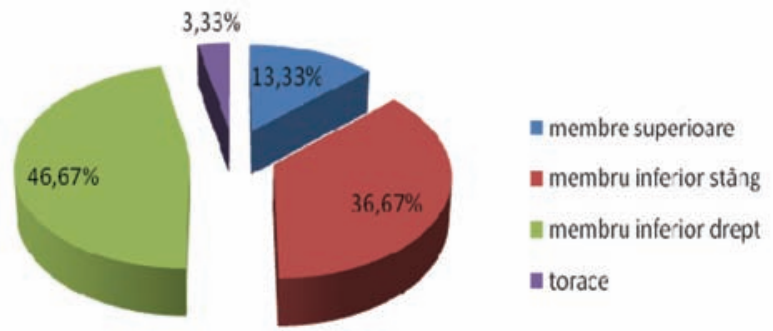

Proporția plăgilor înțepate între membrele inferioare

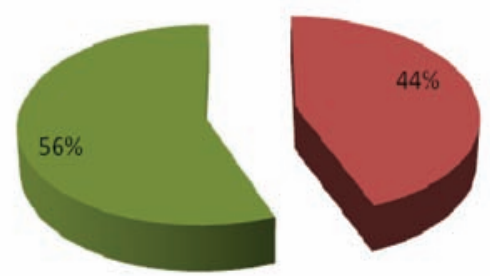

- membru inferior stàng membru inferior drept

Fig. 20. Dispoziția plăgilor înțepate pe segmentele corpului şi proporția plăgilor tăiate între membrele inferioare

Plăgile contuze predomină la nivelul capului, în special la nivel frontal (Figura 21). 

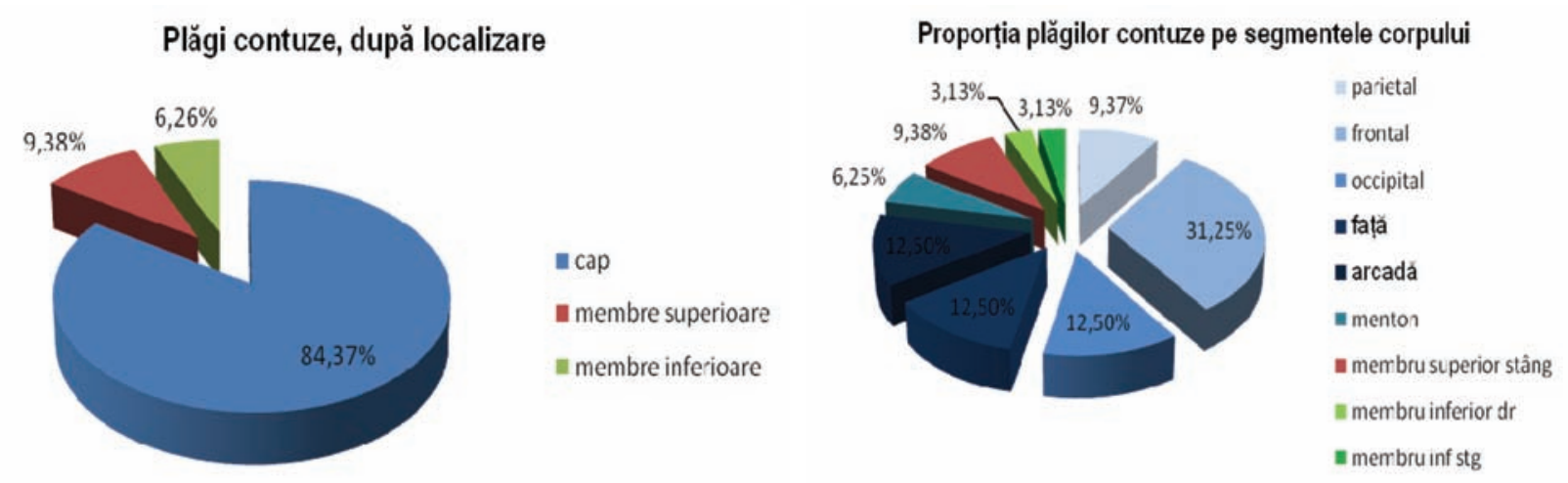

Fig. 21. Dispoziția plăgilor contuze pe segmentele corpului şi proporția plăgilor contuze pe segmentele corpului

În Australia, între 1999-2005 a fost efectuat un studiu [8] privind traumatismele craniene la pacienți peste $60 \mathrm{ani}$, în funcție de vârstă, sex, mediu, tipul de leziune. Rata spitalizărilor pentru traumatisme craniene la populația vârstnică a crescut de 1,4 ori între 1999 (582,8 la mie) și 2005 (844,3 la mie) $(\mathrm{p}<0,001)$. Pacienții peste 85 ani au avut o rată de 10,8 ori mai mare decât grupa 60-64 ani. Bărbații au avut o rată de 1,1 ori mai mare decât femeile, iar locuitorii din rural sau zone isolate o rată de 3,1 ori mai mare decât cei de la oraș. Cel mai frecvent traumatism la nivelul capului a fost plaga deschisă $(38 \%)$, urmată de leziunile superficiale $(24,7 \%)$ și leziunile intracraniene $(18,3)$. Cauzele principale în $81,4 \%$ din traumatismele craniene au fost căderile.

\section{Concluzii}

Pentru traumatisme în general:

1. nu am putut stabili o corelație între variația lunară a consultațiilor și variația lunară a traumatismelor, existând doar o relație de proporționalitate cu numărul consultațiilor.

2. sexul feminin predomină până la 3 ani, când sexul masculin devine preponderent, cu un maxim în grupa de vârstă de 2-3 ani, menținându-se până la grupa de vârstă de peste 60 ani, când se inversează din nou în favoarea sexului feminin. Între 7 și 20 de ani proporția traumatismelor între băieți și fete este aproape constant dublă în favoarea băieților. Traumatismele sunt de 1,87 de ori mai frecvente la sexul masculin.

3. cel mai mic risc pentru traumatisme este al grupelor de vârstă sub un an şi 1-4 ani, cel mai mare fiind la grupa 5-20 ani, de aproape două ori și jumătate mai mare decât la grupele de 20-60 ani și peste 60 ani, la acestea ultime două fiind sensibil egal.

4. există o predispoziție generală pentru toate tipurile de traumatisme a grupei de vârstă 5-18 ani, cu un maxim de risc pentru luxaţii și unul relativ egal pentru plăgi, contuzii și fracturi. La peste 60 ani se observă o tendință de creștere a riscului pentru fracturi comparativ cu alte tipuri de traumatisme, cu o scădere semnificativă a celui pentru luxații.

5. ca frecvență pe primul loc, cu mai mult de jumătate din cazuri, sunt leziunile traumatice deschise (plăgile și contuziile), apoi afecțiunile musculare (întinderi, rupturi), luxațiile și entorsele, fracturile membrelor superioare, fracturile membrelor inferioare.

Pentru fracturi și luxaţii:

1. după localizare, pe primul loc sunt membrelor superioare cu peste jumătate din cazuri, urmate de cele ale membrelor inferioare cu o treime, apoi ale trunchiului şi gâtului, capului și oaselor feței, pe ultimul loc fiind cele ale coloanei vertebrale.

2. cel mai mare număr de cazuri de fracturi s-a înregistrat la populația activă de 20-60 ani, urmată de grupa 8-14 ani, apoi 15-20 ani, la grupele sub 1 an și 2-3 ani nefiind înregistrat nici-un caz. Indicele de risc pentru fracturi urmează tendința indicelui de risc global pentru 
traumatisme, cu maxim la 5-20 ani și mai redus la 0-1 ani, dar mai crescut decât indicele mediu la peste 60 ani.

3. incidența luxațiilor este mai mare decât a fracturilor la grupele de vârstă de 8-14 și 15-20 ani. Indicele de risc pentru luxații depășește semnificativ riscul mediu pentru traumatisme la grupa de vârstă 5-18 ani și scade semnificativ la grupa de peste 60 ani.

Pentru leziuni traumatice superficiale:

4. predomină ca număr de cazuri la grupa 20-60 ani, cu excepția plăgilor contuze, unde numărul maxim este la grupa 5-7 ani. Numărul cazurilor de plăgi înțepate față de alte tipuri de leziuni este maxim la grupa 15-20 ani.

5. în cazul plăgilor mușcate, plăgilor înțepate și plăgilor contuze, există o predominanță a sexului masculin, cu o echilibrare a riscului între sexe pentru plăgi tăiate, contuzii și alte tipuri de leziuni superficiale. Sexul masculin are o predispoziție pentru traumatisme superficiale (plăgi tăiate, înțepate, mușcate, contuze și contuzii), față de alte tipuri de traumatisme (fracturi, luxații, etc), pentru grupele 8-14 ani și 15-20 ani, la celelalte grupe de vârstă existând o predominanță a sexului feminin, cu mențiunea că la grupa 2-3 ani există o deviație de 15 ori mai mare, în favoarea sexului feminin față de traumatisme în general.

6. plăgile contuze o valoare peste medie a riscului pentru grupa de vârstă $1-4$ ani și 5-18 ani, cu o scădere semnificativă a riscului pentru 19-60 ani și peste 60 ani. La grupa sub un an riscul pentru plăgi contuze, mușcate, tăiate, înțepate, și pentru contuzii este practic nul, existând risc moderat pentru alte tipuri de leziuni traumatice. Pentru toate tipurile de plăgi grupa de vârstă de 5-18 ani este cu risc maxim, riscul pentru plăgi tăiate și înțepate scăzând semnificativ peste 60 ani. Riscul pentru plăgi mușcate și contuzii depășește semnificativ media la grupa de vârstă de peste 60 de ani, iar pentru plăgile tăiate grupa de vârstă de 19-20 ani prezintă risc peste medie, deși numărul total de plăgi tăiate este mai mare la grupa 20-60 ani.

7. există o predominanță față de media traumatismelor superficiale a sexului masculin la grupele de vârstă 2-3 ani, cu excepția contuziilor, cu menținerea predominanței la 3-4 ani și la 5-7 ani, precum și peste 60 de ani, doar la plăgile contuze. În cazul plăgilor mușcate, predomină afectarea sexului masculin peste media leziunilor traumatice superficiale la grupele 15-20, 20 60 și peste 60 ani, precum și pentru plăgile înțepate la 20-60 și peste 60 ani.

8. plăgile tăiate predomină la membrele superioare, membrul superior stâng fiind semnificativ mai frecvent afectat.

9. plăgile înțepate sunt mai frecvente la membrele inferioare, cu predominanța afectării membrului inferior drept.

10. plăgile contuze predomină la nivelul capului, în special la nivel frontal.

\section{Referințe}

1. Waller JA, Skelly JM, Davis JH. Treated injuries in northern Vermont. Accid Anal Prev 1995;27(6):819-28.

2. Powell EC, Tanz RR. Adjusting our view of injury risk: the burden of nonfatal injuries in infancy. Pediatrics 2002;110(4):792-6.

3. Labbé J, Caouette G. Recent skin injuries in normal children. Pediatrics 2001;108(2):271-6.

4. Sengoelge M, Bauer R, Laflamme L. Unintentional child home injury incidence and patterns in six countries in Europe. Int J Inj Contr Saf Promot 2008;15(3):129-39.

5. Gedeborg R, Engquist H, Berglund L, Michaelsson K Identification of incident injuries in hospital discharge registers. Epidemiology 2008;19(6):860-7.

6. Dwyer JP, Douglas TS, van As AB. Dog bite injuries in children - a review of data from a South African paediatric trauma unit. S Afr Med J 2007;97(8):597-600. 
7. Mack KA, Gilchrist J, Ballesteros MF. Injuries among infants treated in emergency departments in the United States, 2001-2004. Pediatrics 2008;121(5):930-7.

8. Jamieson LM, Roberts-Thomson KF. Hospitalized head injuries among older people in Australia, 1998/1999 to 2004/2005. Inj Prev 2007;13(4):243-7. 